\title{
FILOZOFIA AKO ŽIVOTNÝ PROGRAM Nad knihou Sarah Bakewellovej V existencialistické kavárně
}

\author{
TATIANA SEDOVÁ, Filozofický ústav Slovenskej akadémie vied, Bratislava, SR \\ SEDOVÁ, T.: About Philosophy like Project for Life. Some Reflections on Book \\ At the Existentialist Cafe by Sarah Bakewell \\ FILOZOFIA, 75, 2020, No 4, pp. $324-330$ \\ Essay deals with existential phenomenology, focusing on question its nowadays \\ importance especially regarding freedom and authenticity in current society. \\ The author describes development of existentialism on the background and with \\ respect to the book At the Existentialist Cafe by S. Bakeweell, and states that \\ there is increasing interest in what existential phenomenology means todays.
}

Keywords: Existencialism - Phenomenology - Bakewell - Sartre - Merleau-Ponty - Freedom - Lived experience

Hoci satirický Filozofický lexikón ${ }^{1} \mathrm{z}$ dielne editorskej dvojice D. Dennetta a Asbjørna Steglich-Petersena uvádza pod heslami merleau-ponty, heidegger, husserl, z ktorých robí adjektíva (na Sartra sa ešte nedostalo) ironizujúce charakteristiky hlavných filozofických téz daných postáv, práve títo myslitelia, ktorých satirický lexikón konvertoval na prídavné mená spolu s inými - najmä Sartrom a de Beauvaiorovou - sú protagonistami pozoruhodnej knihy, ktorá ma prinútila zamysliet' sa nad osudmi a peripetiami existencializmu, a čiastočne aj fenomenológie. Existencializmus po svojom oslnivom vzostupe po druhej svetovej vojne v osemdesiatych rokoch takmer vymizol zo scény, aby uvol'nil miesto pod slnkom iným prúdom. Treba však uznat', že jeho reflexie nad ludskou existenciou, jej modalitami a štruktúrami, demonštrovanými najmä v pocitoch a náladách, boli presvedčivo prezentované skôr v literárnych žánroch, ktoré si

\footnotetext{
${ }^{1}$ Pozri https://www.philosophicallexicon.com/ a preklad hesla heidegger $\mathrm{v}$ knihe Bakewellovej $(2019,60)$ výraz heidegger ,jako myšlenkové zařízení k vrtaní do mohutných vrstev podstaty“. In the wrong order, with confused foundations, said of a theory; figurative synonyms are upside-down, topsy-turvy, front-to-back. "The sense-datum approach to certainty was all merleau-ponty in the first place" (pozri https://www.philosophicallexicon.com/ heslo merleau-ponty). To surround a simple phenomenon with darkness to create the illusion of seeing it more clearly afterwards; if it fails, one probably has to use a heidegger (q. v.). Pozri https://www.philosophicallexicon.com/ heslo husserl.
} 
našli vd’ačné auditórium, ako v suchopárnych filozofických traktátoch. Vd’aka tomu hlboko prenikli a zakorenili v rozličných kultúrnych podobách, takže si ich pôvod a väzbu na existencializmus vlastne ani neuvedomujeme. Áno, neskôr existencializmus vytesnili iné prúdy, ktoré l’udskú existenciu a otázky typu Čo je človek?, Aká je povaha jeho slobody?, pokladali za beznádejne antikvovaný projekt. Tieto prúdy preferovali skúmanie znakov, štruktúr, vzt'ahov a významu. Dejiny filozofie sú panteónom ideí, konceptov, systémov, ale tento panteón zahíňa aj osudy ich tvorcov a nositel'ov, pričom adept filozofie stojí pred hádankou, či uprednostnit' idey, alebo osudy ich nositel'ov. V rozličných obdobiach svojej kariéry si vyberá jedno alebo druhé, aby pri nejakej náhlej iluminácii zmenil pôvodný názor. Príbeh filozofie, ak sa obmedzíme na jej európsku tradíciu a nebudeme pokukovat' po východnej filozofii, má mnohoraké verzie a vygeneroval aj filozofické sústavy, ktoré zanechali výraznú stopu v svetovej filozofii, kultúre a literatúre, ale aj takých, ktorí si užili svojich pät' minút slávy, aby následne upadli do zabudnutia. To, že tieto myšlienkové sústavy sa z tohto anihilovaného stavu môžu prebudit' a chytit' druhý dych, sa vonkoncom nevylučuje, a aj $\mathrm{v}$ tom spočíva rozdiel medzi filozofiou a vedou, ktorá sa nikdy nevracia $\mathrm{k}$ raz falzifikovaným koncepciám, ideám a predstavám.

K tým filozofiám, ktoré prežili svoj vzostup aj pád, aby sa opät' prihlásili o slovo, nepochybne patrí fenomenológia, predovšetkým v zmysle metódy skúmania, o čom svedčí jej aplikovanie aj v takej oblasti, akou je neurológia (napr. O. Sacks), v kognitivizme, v ktorom fenomenologická idea vtelenej kognície našla svoje uplatnenie, ale rovnako sa presadilo aj chápanie vedomia ako holistického sociálneho fenoménu, na rozdiel od jeho chápania v intencii analógie s počítačom. Myšlienky telesnosti, opisu fenoménov, povaha a podstata vnímania, prežívanie skúsenosti, jej rozmanité podoby (všetko koncepty $z$ arzenálu fenomenológie) sa čoraz viac presadzujú $\mathrm{v}$ rozličných skúmaniach aj na pomedzí filozofie a vedy.

Príbeh existencializmu, ktorý za mnohé vd’ačí fenomenológii, je zároveň politický aj historický, v istom zmysle je to príbeh európskeho dvadsiateho storočia, ako oprávnene tvrdí autorka tejto knihy. Dvadsiate storočie bolo storočím extrémnych ideológií, aj mimoriadneho utrpenia. A toto poznačilo existencialistické uvažovanie, pričom fenomenológia sa zrodila pred prvou svetovou vojnou a počas nej. Existencializmus, ktorý ovplyvnil celú jednu epochu, aby potom zmizol zo scény, je dnes vnímaný skôr v rovine literatúry a dramatickej tvorby, pretože Camusove diela Mor, Caligula, Mýtus o Sizyfovi a Sartrove Muchy, Nevol’nost', S vylúčením verejnosti, Špinavé ruky sú rozhodne známejšie v zmysle literárnej popularity, než ako vlastná filozofická spisba (napr. Sartrova kniha Bytie a ničota). Samozrejme, v zmysle predmetu skúmania, nech už dejinno-filozofického alebo kultúrno-politického, existencializmus ostal implicitne prítomný ( $\mathrm{v}$ tomto zmysle treba brat' Bakewellovej tvrdenie cum grano 
salis) aspoň vo Francúzsku. V tejto súvislosti ma slovenská filozofka, odborníčka na francúzsku filozofiu dvadsiateho storočia a Sartra D. Smreková, upozornila na zoskupenie známe pod akronymom G.E.S (Groupe d'études sartriennes), ktoré sa venuje interpretácii a výkladom ranej a doposial' nedostatočne preskúmanej práce Náčrt teórie emócií, ale aj Sartrovej etiky a filozofie dejín. ${ }^{2}$

Hoci metóda interpretovania filozofie na základe osobnosti jej tvorcu zväčša nebýva práve najlepší spôsob na porozumenie jeho či jej ideám, názorom a postojom, lebo aj filozof je len človek z mäsa a kostí, so všetkými chybami a nedostatkami charakteru; kniha z pera britskej autorky Sarah Bakewellovej je v tomto smere výnimkou. Ide totiž o vydarenú symbiózu, v ktorej si podávajú ruky životné osudy, filozofické myšlienky, história aj kultúrna analýza.

Ústrednými postavami autorkinho rozprávania sú Simone de Beauvoirová, JeanPaul Sartre, Raymond Aron, ale aj Martin Heidegger a Maurice Merleau-Ponty. V knihe vystupujú aj iné postavy, niektoré dobré známe - ako Karl Jaspers, Gabriel Marcel, Hannah Arendtová a i. -, d’alšie, aspoň v domácom kontexte menej známe osobnosti ako Jean Beaufret (práve jeho otázky motivovali Heideggera, aby napísal List o humanizme, 1947), Walter Kaufmann, Francis Jeanson a mnoho d’alších. Všetky osoby, ktoré sa v knihe objavia, sumarizuje kapitolka Kto je kto v prípade potřeby $(313$ - 320) so stručnými medailónikmi, a tu ihned' dodávam, že sama osebe stojí za prečítanie.

Kniha je dozaista aj osobným vyznaním filozofickej viery, holdom Sartrovi, ktorý autorku motivoval, aby zanechala školu, ,zanedbávala svoje štúdiá kvôli svojej existencii“, ale zároveň ju napokon donútil zložit’ maturitu a študovat’ filozofiu.

V štrnástich kapitolách s názvami znejúcimi provokatívne, ambivalentne až dekadentne: Pane, jaká hrůza - existencialismus!, K věcem samým, Kouzelník z Messkirchu, To ono volání, Chroupat kvetoucí mandloně, Nechci jist své rukopisy, Okupace, osvobozeni, Zpustošeni, Škola života, Filozof tanečnik, Croisés comme ça, Očima toho nejméně privilegovaného, Stačí jednou ochutnat fenomenologii, Nepostižitelný pel, ku ktorým sa pridávajú kapitoly Postavy, Poděkování a Register), sa pred vnútorným zrakom čitatel'a odvíja príbeh postáv, pre ktoré bola filozofia skôr životným programom ako suchými abstraktnými tézami. J.-P. Sartre je toho jedinečným príkladom, lebo dokázal vstrebat' a transformovat' fenomenológiu na l'udský život tak, že vo svojich poviedkach, románoch, hrách, ale aj vo filozofických traktátoch písal o telesnom vnímaní sveta, štruktúrach a náladách l'udskej existencie, ale najmä o jednej téme,

\footnotetext{
${ }^{2}$ B.-H. Lévy venoval svoju monografiu Sartrovo století (2003) rozboru Sartrovho myšlienkového vývoja aj osobných premien. Zasvätený výklad Sartrovho filozofického odkazu, jeho recepcii $\mathrm{v}$ českom aj slovenskom prostredí je venovaná stat' z pera D. Smrekovej Téma sociálneho a historického v existencializme Jeana-Paula Sartra. In: Novosád, F., Smreková, D. 2013, 611 - 632). V tejto obsiahlej stati sú uvedené aj hlavné interpretátorske línie spolu s českými a slovenskými prekladmi.
} 
o tom, čo značí byt' slobodným. Hoci človeka determinuje tak moja biologická prirodzenost', ako aj rozličné aspekty sociálneho a kultúrneho prostredia, nič z toho nepredurčuje, akí napokon v konečnom dôsledku budeme. Sami seba ustavične formujeme, utvárame a modelujeme. Formulka Existencia predchádza esenciu vyjadruje poznanie, že sme svojou vlastnou slobodou. Sartre pokladal tému slobody za absolútne kl'účovú, pričom odmietal všetky esencialistické koncepcie, či už biologické, sociologické alebo psychologické, lebo človek nie je len svojou faktickou existenciou, ktorá je podmienená sociálne a biopsychologicky, ale vždy je aj bytím pre seba; v každej situácii má toto bytie pre seba možnost' vol'by, možnost' angažovat' sa v situácii. Práve $\mathrm{v}$ tomto zmysle je človek akoby odsúdený na slobodu, a teda aj na zodpovednost'. Prirodzene, toto chápanie, ktoré je podla môjho názoru skôr antropologicko-filozofické ako sociálno-politické, možno kritizovat' z rôznych aspektov, ale svojín naliehavým apelom na neoddelitel'nost' slobody od situácie stojí za to, aby sme toto chápanie slobody, situácie a zodpovednosti aj dnes opät' vzali na vedomie.

Po vojne v roku 1945 sa všetky tradičné politické aj spoločenské autority otriasali vo svojich základoch, správy o nacistických zločinoch a Hirošima a Nagasaki usvedčili l'udí, že dokážu konat' v rozpore s civilizovanými normami, predstavy o nemenej l'udskej prirodzenosti sa spochybnili. Sartrova filozofia donútila človeka, aby dospel a pripravil sa na prevzatie zodpovednosti. Inštitúcie, ktoré Sartre spochybnil, reagovali tak, že katolícka cirkev umiestnila na index jeho knihy, rovnako aj de Beauvoirovej Druhé pohlavie.

Marxizmus nenašiel na Sartrovi nič pozitívne, čo sa dá pochopit', ked’že myšlienka osobnej zodpovednosti $\mathrm{v}$ koncepcii, kde cesta do socialistického raja predpokladala zákonité štádium vývoja, nemá adekvátne miesto a funkciu. Podobne ako v dobách parížskej bohémy, dadaizmu, v revoltujúcom svete existencializmu bolo dobré všetko provokatívne a všetko označené ako malomeštiacke bolo zlé. Previazanost' svojej filozofie a života u Sartra viedla k záujmu o iných, nie náhodou napísal štúdie o Mallarmém, Genetovi, Flaubertovi, Baudelairovi, ale aj memoáre o svojom detstve a dospievaní. Hoci premostenie filozofie a života, praktizovanie dobrého života nie je nič nové, o tom bola filozofa stoikov a epikurejcov, podl’a ktorých filozofia je otázkou ako plnohodnotne a l'udsky zodpovedne žit'. Ale až existencialisti dali ponímaniu filozofie ako životného programu novú dimenziu. Dimenziu autentickosti a nonkonformizmu, ktorá vrcholila vo feministickom diele Simone de Beauvoirevej z roku 1949 Druhé pohlavie.

Revolučná vlna robotníkov a študentov v roku 1968 sa niesla v znamení existencialistických tém. „Sartre byl mostem ke všem tradicím, z nichž sám čerpal, modernizoval je uzpůsoboval a přetvářel. Přesto celý život trval na tom, že nezáleží na minulosti, jen 
na budoucnosti. Člověk se musí posouvat dál a tvořit osobním to, co bude: jednat ve světě a působit v něm změnu“ (Bakewellová 2019, 30).

Oslobodenie Francúzska znamenalo d'alší rozkvet existencializmu, ale aj okúzlenie Amerikou (USA), ktorá symbolizovala budúcnost', respektíve jednu jej alternatívu, kým druhú nepochybne ponúkal Sovietsky zväz. V tomto bode sa cesty a názory jednotlivých stúpencov a protagonistov existencializmu rozchádzali a Bakewellová opisuje ich rozchody a nezhody, ktoré sú v mnohom paradigmatickým príkladom večného sporu o angažovanost' filozofa vo verejnom priestore a hlavne v politike. Skúšobným kameňom sa stal aj postoj k maoizmu. V knihe sú citlivo a s pochopením pre jednotlivé charaktery zachytené aj osobné vzt’ahy mužských aj ženských postáv, ich stretávania a rozchody. Treba poznamenat', že v USA však obraz existencializmu nadobudol pochmúrnu, depresívnu podobu pesimistickej duše prežívajúcej strach a úzkost', z čoho sa stalo klišé pri zobrazovaní existencialistov napríklad vo filme.

V kontexte historických udalostí a politiky autorka Heideggera, o ktorom od roku 1934, ked' odstúpil z pozície rektora Freiburskej univerzity, nebolo na verejnosti vel'mi počut'. Jeho myslenie sa začalo menit' už pred vojnou, od problematiky bytia k smrti, od analýz Dasein a nárokov naň kladených sa obrátil k jazyku, technike, mechanickosti vecí, venoval pozornost' jazyku, technike a mechanickosti veci, zároveň musel čelit' otázkam o jeho vzt'ahu k nacistickému režimu a jeho ideológii. Táto nepríjemná škvrna od neho odvrátila aj bývalých stúpencov (E. Levinas, H. Marcuse) a Bakewellová opisuje aj jeho vzt’ahy s Jaspersom, Husserlom, (Heidegger sa nezúčastnil ani jeho pohrebu, Husserl zomrel 27. apríla 1938) a Arendtovou. ${ }^{3}$ Podrobne referuje aj o stretnutí so Sartrom v roku 1953 na Freiburskej univerzite, ktoré bolo vel'kým sklamaním.

Dvojznačnost' l’udského údelu, ktorý osciluje medzi našimi limitujúcimi obmedzeniami, a neustálym úsilím o ovládnutie situácie, prelínanie kontingencie a slobody, nezmieritel'nost' s osudom, komplexnost' l'udskej existencie, ktorú podl'a autorky najlepšie postihli de Beauvoirová a „veselý filozof, vecí, takých, aké sú“ Merleau-Ponty, to sú témy, ktoré aj dnes oslovujú, a to nielen akademikov. Práve druhú postavu, ktorá spájala psychológiu (najmä Gestalt psychológiu) s filozofiou, pokladá Bakewellová za svojho hrdinu (Bakewellová 2019, 311), ktorý najlepšie zachytil naše prežívanie skúsenosti a to, čo bolo na periférii záujmu, presunul do centra filozofického skúmania - telo, detstvo, sociálnost', vnímanie (Fenomenológia vnímania). Práve jeho myšlienkové dedičstvo dnes asi rezonuje najsilnejšie. Poučné je aj jeho uvažovanie späté s psychológiou, hlavne klinickou, ktorú nevyužíval len na ilustrovanie abstraktných

\footnotetext{
${ }^{3} \mathrm{O}$ peripetiách Arendtovej vzt’ahu s Heideggerom pozri napr. Ettingerová, E.
} 
filozofických téz, ale ako nástroj na objasňovanie fenoménov, ktoré filozoficky tematizoval.

V osemdesiatych rokoch 20. storočia očarenie existencializmom a myšlienkou, že „život je jedna vel'ká existencialistická kaviareň“, vyprchali. Nastúpili iné -izmy, nová generácia štrukturalistov, postštrukturalistov, dekonštruktivistov, postmodernistov. Napriek vzájomnému nesúhlasu zhodne odmietali existencializmus a fenomenológiu, biografia bola nezaujímavá, ošial' zo slobody a existenciálne úzkosti boli na posmech. Filozofia bola opätovne nasmerovaná na šíre more abstrakcie. Problémy 21. storočia sa líšia od problémov 20. storočia, svet sa zmenil, čo značí, že asi aj vo filozofii dnes hl'adáme niečo iné. Ale úzkosti, staré a nové obavy, hraničné existenciálne situácie a ambiguita osudu nielen jedinca, ale dnes už celého l’udstva, hlasy volajúce po zodpovednosti za budúce, do detailov nepredvídatel'né dôsledky našich dnešných rozhodnutí a činov, volanie po novej etike a solidarite, dávajú existencializmu druhý dych a novú šancu.

Povedané spolu s autorkou zmenila sa aj jej optika a novými očami pozerá na Heideggera, Camusa, Marcela, Sartra, Merlau-Pontyho (najmä na jeho Fenomenológiu vnímania), zmenila sa aj ona sama. Kladie si otázku, čo nám môže ponúknut' existencializmus dnes, ked' sa rozpadol bipolárny svet, nové technológie menia podobu sveta, komunikáciu aj l’udskú prirodzenost', pričom sa objavili nové podoby útlaku, nerovnosti a úzkosti. Sloboda, ktorá na prvý pohl'ad akoby začala vítaanné t’aženie, aspoň podl'a optiky neoliberalizmu, však v rovine politickej aj osobnej stále predstavuje problém, práve tak ako vztahy slobody a l’udských práv. Dnešné civilizačné problémy, ktoré podkopávajú samu existenciu človeka ako druhu, postupujúca devastácia životného prostredia, dehumanizácia, presýtenost' spotrebným konzumným spôsobom života, vznik nových foriem odcudzenia, senzibilita absurdity aj vd’aka novým komunikačným technológiám, ale aj hrozby z rozvíjania umelá inteligencia (artificial intelligence - $\mathrm{AI}$ ), pretrvávanie starých a vznik nových foriem útlaku, zneuznania a nerovností, to všetko akoby signalizovalo, že posolstvo existencializmu - sloboda a politická angažovanost' - sa vracia. Tieto javy akoby boli ozvenou existencialistických tém: ,,... pak nám návrat $k$ existencialistům disponujícím odvahou a energií může nabídnout určitou novou perspektivu. Existencialisté jen tak nečinně neposedávali a nehráli si s významy slov" (Bakewellová 2019, 35). Povedané spolu s autorkou: „Právě proto při četbě Sartrových textu o svobodě, Beauvoirové o důmyslných mechanismech útlaku, Camusových o vzpouře, Heideggerových o technologiích či Merleau-Pontyho o kognitivní vědě má člověk někdy pocit, jako by četl aktuální zprávy. Jejich filozofie zůstávají ve střede zájmu nikoli proto, že by měli pravdu nebo se mýlili, ale proto, že se dotýkají života, a proto, že se zabývají dvěma největšími otázkami lidství: Čím jsme? a Co bychom méli dělat?" (Bakewellová 2019, 36). 
Domnievam sa, že odkaz existencializmu možno v súčasnosti vnímat' aj rozvíjat' v dvoch rovinách; jednu predstavuje otázka slobody, jej podôb na úrovni osobnej a sociálno-kolektívnej, druhá rovina zahíňa politické aspekty slobody. Kým v prvom prípade vstupuje do hry problém autentickosti a autonómie indivídua, $\mathrm{v}$ druhom prípade je rozhodujúci vzt’ah slobody, respektíve slobôd k l'udským právam, ich zdroju, platnosti a rozširovaniu. $V$ tomto smere pokladám ideové dedičstvo existencializmu a fenomenológie za stále aktuálne a doposial’ dostatočne nezužitkované, lebo: „,... pochopit' svet znamená pre človeka zredukovat' ho na l'udské, vtlačit' mu l'udskú pečat““ (Camus 1993, 16).

\section{Literatúra}

BAKEWELLOVÁ, S. (2019) : V existencialistické kavárne. Brno: Host.

CAMUS, A. (1993): Mýtus o Sizyfovi, Pád, Caligula. Bratislava: Slovenský spisovatel'. ETTINGEROVÁ, E. (2004): Hannah Arendtová a Martin Heidegger. Praha: Academia.

NOVOSÁD, F., SMREKOVÁ, D. (2013): Dejiny sociálneho a politického myslenia. Bratislava: Kalligram.

Príspevok vznikol v rámci riešenia projektu VEGA 2/0049/20 Kidei l’udských práv: filozofická perspektiva - koncepty, problémy a protiklady.

Tatiana Sedová

Filozofický ústav SAV

Klemensova 19

81364 Bratislava

Slovenská republika

e-mail: tanasedova@gmail.com

ORCID ID: https://orcid.org/0000-0003-1888-9592 